\title{
The Treatment of Terms Relating to Islam and the Arab World in English Dictionaries*
}

\author{
Hashan Al-Ajmi, Department of English, Faculty of Arts, Kuwait University, \\ Kuwait (hashan98@yahoo.com) and

\section{Abdullah Al-Otaibi, Department of English, Public Authority for Applied} \\ Education and Training, Kuwait (dr_alotaibi@yahoo.com)
}

\begin{abstract}
This article investigates the treatment of vocabulary items relating to Islam and the Arab world in three major English dictionaries: Longman Dictionary of Contemporary English, New Oxford Dictionary of English, and Merriam-Webster's Collegiate Dictionary. The three dictionaries are compared with regard to their inclusion of 73 Arabic items (including loanwords) used in texts on Islam and the Middle East at the Google news file. With religion as theme, eight of these terms have been examined and compared across their entries in these three dictionaries to determine the closeness of the lexicographic description of these terms to their original meanings among native speakers of Arabic and to detect, from these speakers' viewpoint, any deficiencies in the defining language of their respective entries. The examination of the definitions of terms relating to Islam and the Arab world in the three dictionaries has revealed a number of pitfalls that may require editorial reconsideration. These include circularity, insufficient information, negative contexts, very general definitions, ambiguity, incomplete information, narrow definitions and encyclopedic redundancy.
\end{abstract}

Keywords: ARABIC LOANWORDS, CULTURAL TERMS, DEFINITION, ISLAM, REPRESENTATION, LEXICOGRAPHY

Opsomming: Die behandeling van terme betreffende Islam en die Arabiese wêreld in Engelse woordeboeke. Hierdie artikel ondersoek die behandeling van woordeskatitems betreffende Islam en die Arabiese wêreld in drie vooraanstaande Engelse woordeboeke: Longman Dictionary of Contemporary English, New Oxford Dictionary of English, en MerriamWebster's Collegiate Dictionary. Die drie woordeboeke word vergelyk met betrekking tot hul opname van 73 Arabiese items (insluitende leenwoorde) wat in tekste oor Islam en die Midde-Ooste in die Google-nuuslêers gebruik word. Met godsdiens as tema, is agt van hierdie terme ondersoek en vergelyk met hul inskrywing in dié drie woordeboeke om die nabyheid vas te stel van die leksikografiese omskrywing van hierdie terme aan hul oorspronklike betekenisse onder moedertaalsprekers van Arabies, en om vanuit hierdie sprekers se gesigspunt enige gebreke op te spoor in die definisietaal van hul onderskeie inskrywings. Die ondersoek van die definisies van terme betref-

This article was presented as a paper under the title 'The Presentation (or Misrepresentation) of Arabic-Islamic Culture in English Dictionaries' at the 51st Annual International Linguistic Conference, York University, Toronto, Canada, 31 March - 2 April 2006.

Lexikos 16 (AFRILEX-reeks/series 16:2006): 1-12 
fende Islam en die Arabiese wêreld in die drie woordeboeke het 'n aantal slaggate blootgelê wat moontlik redaksionele heroorweging nodig maak. Dit sluit in sirkulariteit, onvoldoende inligting, negatiewe kontekste, baie algemene definisies, dubbelsinnigheid, onvolledige inligting, beperkte definisies en ensiklopediese oortolligheid.

Sleutelwoorde: ARABIESE LEENWOORDE, KULTURELE TERME, DEFINISIE, ISLAM, VERTEENWOORDIGING, LEKSIKOGRAFIE

\section{Introduction}

A dictionary may be defined as a reference work that documents the culture of the speakers of a given language and also reflects their knowledge and view of other cultures. Dictionaries, however, may not always provide objective, clear and accurate information about cultural terms borrowed from other languages. A related case here is the treatment of terms relating to Islam and the Arab world in English dictionaries.

Since the oil crisis of 1973, there has been a noticeable trend in the West to learn more about Islam and the Arabs. The political events of the times have shown that there is greater need for a better understanding of Islam and the Arab world where religion plays a pivotal role. Such a need has been emphasized by the UNESCO Universal Declaration on Cultural Diversity (2 November 2001) which promotes the 'fruitful diversity of ... cultures' for a more open and creative world in the new 21st century context.

Still, there exists a great deal of misunderstanding in the West of Islam and the Arab world and recent incidents are indicative of a deeply-rooted misunderstanding between Christian Westerners and Muslims. There can be referred to the use, although atypical, of the word crusade by Western political leaders when referring to the Afghan war and the anger that term caused among many Muslims.

It is widely believed nowadays that Western media emphasize further negative images of Muslims largely for political reasons. Poole (2002: 47) provides, 'as an example of how prevalent themes are adapted to suit the political purposes of the time, the image of the oil-rich Sheikh with his harem, which dominated the 1970s following the oil crisis'. One of Poole's conclusions about the portrayal of Muslims in the media is that 'it is a representation that appears to tell us more about the representers than the represented'.

\section{Metalexicographic background}

Dictionaries, which are records of not only language and culture but also of a nation's view of other cultures, may not reflect the reality of the other. The lexicographic description of foreign cultures is supposed to be done carefully and objectively since a dictionary, as an unquestionable and supposedly impartial authority, is consulted by thousands or millions of users seeking both linguistic 
and encyclopedic information about foreign cultural terms. However, as Moon (1989: 75) observes, 'dictionaries provide the world views of their lexicographers'. In turn, lexicographers are influenced by the social groups to which they belong. In the words of Landau (1989: 303), dictionaries express 'the views and prejudices of the established well-educated, upper classes'. This notion of social influence on a lexicographer's work is stressed by Cowie (1995: 283): 'both the content of a dictionary and its organization are strongly indicative of the values, judgements and priorities of the society in which the dictionary is compiled'.

A few studies have found that foreign cultures are underrepresented or misrepresented in English dictionaries. Benson (1997: 1) shows in his analysis that China is represented as peripheral at the levels of the wordlist, definitions, labels and illustrative text. He noticed that there may have been biases in the composition of the corpus and the selection of items from it and suggested that the selection of items expresses a Western perspective on China, not a Chinese perspective. Another study, Brown (1996), examined the treatment of religious terminology in four EFL dictionaries and found that there exists a great deal of inaccuracy in the definitions of Islamic terms and that these terms have been given a Western interpretation. The study asked the question: 'Whose definition of jihad or Mecca should appear in English dictionaries: Muslims or nonMuslim English speakers?' Brown (1996: 313) also refers to the role of corpora containing English speech and writing: 'any definition based on the corpus must represent the incorrect and potentially offensive meaning given to the term by those non-Muslim English speakers'.

In the metalexicographic literature on cultural information in dictionaries, repeated mention of the negative representation of Muslims are found. Burchfield (1989: 20) refers to an incident where the word Palestinian was defined in COD (Concise Oxford Dictionary) as someone 'seeking to displace Israelis from Palestine', causing an angry protest from Palestinian groups demanding a correction of the entry. More recently, an entry, which appeared on the online version of Roget's Thesaurus, listing the word Arab as a noun meaning "beggar," and "homeless person" along with 14 other pejorative synonyms, was received with protests in the Arab world and letters of complaint were sent to the publishers who responded by removing the entry from the site.

\section{Aims of the study}

The present study aims to examine the treatment of vocabulary items relating to Islam and the Arab world in three major English dictionaries: Longman Dictionary of Contemporary English (LDCE), New Oxford Dictionary of English (NODE), and Merriam-Webster's Collegiate Dictionary (Webster's). Firstly, Arabic terms relating to religion have been gathered in a search-list and looked up in the three dictionaries to compare the dictionaries on the basis of their inclusion. Secondly, a group of eight terms have been examined and compared across 
their entries in the three dictionaries to determine how close or distant the lexicographic description of these terms is to or from their original meanings among native speakers of Arabic and to detect, from these speakers' viewpoint, any deficiencies in the defining language in their respective entries.

\section{The dictionaries}

The three dictionaries have been chosen because they serve as good representatives of three different dictionary types used by both native speakers and foreign learners of English: EFL (LDCE), encyclopedic (NODE), and native speakers' (Webster's) dictionary. This selection is aimed at revealing differences at the levels of vocabulary inclusion, objectivity of description and adequacy of details across the three types in their representation of Islam and the Arab world.

LDCE is the representative of the EFL type of dictionary. It is probably the most popular dictionary among foreign learners of English around the world. Therefore, its simplified definitional style should be examined vis-à-vis its treatment of terms relating to Islam and the Arab world.

NODE has been chosen because this encyclopedic dictionary enjoys wide popularity among different categories of users worldwide. It is expected that such a dictionary will contain more of these terms than the other two and its more detailed etymological treatment of vocabulary makes it a reliable reference work for many users. It should be noted that the 2003 edition with the title Oxford Dictionary of English was also examined and no major changes were noticed with regard to the treatment of Islamic terms.

Native speakers' dictionaries are represented here by Webster's, which also represents American dictionaries. It is regarded as one of the most widely used titles in the United States by both college students and the general public.

\section{Inclusion of Islamic vocabulary in the wordlist}

A list of 73 arbitrarily selected common Islamic terms has been made, using as corpus the Google news file, a huge record of English news sources where the appearance of Islamic items would reflect the reality of usage and frequency of use. The selected items are of high frequency in mostly news reports and articles on Islam and Middle Eastern cultures. The three dictionaries were assessed in terms of their inclusion of the 73 items. As expected, the encyclopedic NODE has turned out to be the dictionary listing more of these items than the other two. Yet, it only contained 51 terms $(69.9 \%)$ followed by Webster's with 33 $(45.2 \%)$ and finally LDCE with only 25 (34.2\%) (see Appendix).

This list of common cultural terms includes words that are frequently used by Muslims regardless of their native languages. Some of these terms have found their way into everyday English in recent years, e.g. halal the con- 
cept of which has even become acceptable in most European countries (Rosen 2002: 150). The low percentages recorded by the three dictionaries indicate the need to revise the amount of this vocabulary in English dictionaries, given the fact that recent years have witnessed an increasing occurrence of these terms in the printed media and other types of literature in addition to the growing interest in the West to read more about Islam and the Middle East.

Another important observation concerns the spelling forms of many terms in the list. It was found that there are clear disagreements in the three dictionaries as to the approved spelling of terms like haj/hadj/hajj, Muhammed/ Muhammad, halal/hallal, hegira/hijra etc. The question here is to what extent have computerized corpora been utilized for determining the most common spellings of these terms. Standardization of these spellings would certainly be welcomed by users engaged in the production of texts on Islam or the Middle East.

\section{Definitions of Islamic terms}

A careful examination of the definitions of terms relating to Islam and the Arab world in the three dictionaries has revealed a number of pitfalls that require editorial reconsideration. These shortcomings include circularity, insufficient information, negative contexts, very general definitions, ambiguity, incomplete information, narrow definitions and encyclopedic redundancy.

\section{(a) Circularity}

In the definition of Islam in NODE, the user is told that it is the religion of Muslims. A similar definition is given in LDCE where the term is defined as the Muslim religion. NODE fails to provide a self-sufficient definition as the user is left with other Islamic terms: Muslim and Allah. Also, the three definitions differ in the inclusion of an essential feature of Islam, i.e. monotheism. LDCE does not refer to the religion as monotheistic.

LDCE Islam ... the Muslim religion, which was started by Muhammed and whose holy book is the Koran ...

NODE Islam ... the religion of the Muslims, a monotheistic faith regarded as revealed through Muhammed as the Prophet of Allah

Webster's Islam ... the religious faith of Muslims including belief in Allah as the sole deity and in Muhammad as his prophet ...

\section{(b) Insufficient information}

As an EFL dictionary, LDCE provides short and simplified definitions for these terms, but its definition of a common term halal, offers only one of two senses 
of the term. Unlike the other two dictionaries, halal is defined as 'meat from an animal that has been killed in a way that is approved by Muslim law'. Here the dictionary reflects English speakers' knowledge of the word, and it is restricted to the gastronomic sense of the word. It should also be noted that NODE gives the original Islamic sense of the word as a secondary meaning in the compound section of the entry. Webster's provides both senses but focuses on the meaning related to food as shown in the illustrative examples halal food and halal restaurant. Users from other cultures will accordingly understand such terms from an English cultural viewpoint rather than from the perspective of the Islamic culture, which may give rise to inadequate understanding at a global level.

LDCE halal ... halal meat is meat from an animal that has been killed in a way that is approved by Muslim law

NODE halal ... denoting or relating to meat prepared or prescribed by Muslim law: halal butchers ... religiously acceptable according to Muslim law: halal banking

Webster's halal ... 1: sanctioned by Islamic law; esp: ritually fit for use $\langle\sim$ foods $\rangle$ 2: selling or serving food ritually fit according to Islamic law $\langle\mathrm{a} \sim$ restaurant $\rangle$

\section{(c) Negative contexts}

The negative context of war is used in the definition of the term jihad in all three dictionaries. They all equate the term with 'holy war', which is to Muslims the lesser form of jihad (Brown 1996). The modern informal English sense of jihad as a 'single-minded or obsessive campaign' is represented in NODE, but the foreign user may not know that this sense does not exist in the original usage of the term. Webster's also gives another sense, as 'crusade' which may have more than one interpretation and the original meaning of the term, 'struggle', is not specified. In its apparent attempt to avoid the mention of who Muslims would fight against, LDCE presents the shortened definition 'a holy war fought by Muslims'. NODE, on the other hand, gives the impression that jihad is fighting those who do not believe in the Muslim religion. This latter meaning may cause offense to Muslims as it considers all non-Muslims to be enemies and reveals the extent to which the concept of jihad, in an ill-represented reality, has been misunderstood in the West.

LDCE jihad ... a holy war fought by Muslims

NODE jihad ... a holy war undertaken by Muslims against unbelievers ... infml: a single-minded or obsessive campaign ...

Webster's jihad ... 1. a Muslim holy war against infidels ... 2. a crusade ... 


\section{(d) Very general definitions}

Some of the terms examined in this study are of a very general nature, thus leading to possible confusion among users. The word Arab, being in itself the subject of successive definitions in history books, is one example that illustrates the point. In Webster's definition of this word historical specificity is lacking as it defines Arab as 'a member of a Semitic people in the Arabian peninsula' while actually Arabs are originally from the southern part of the peninsula. The second sense of the word in Webster's refers to Arabs as members of 'an Arabicspeaking people'. Here the user may wonder whether ethnic groups that also speak Arabic in the Middle East would be described as Arabs. NODE, on the other hand, focuses on the origin of Arabs and neglects the linguistic side. According to NODE's definition the user may think that descendants of pharaohs and Assyrians may not be regarded as Arabs because of their different origins. LDCE combines descent and language in its definition of the word, but the use of the geographical term Middle East is a generalization since this term may be taken as referring to non-Arab regions such as Iran, Turkey and Pakistan.

LDCE Arab ... someone whose language is Arabic or whose family have their origin in Arabia or the Middle East ...

NODE Arab ... a member of a Semitic people, originally from the Arabian Peninsula and neighboring territories, inhabiting much of the Middle East and North Africa ...

Webster's Arab ... 1.a. a member of the Semitic people of the Arabian peninsula $b$. a member of an Arabic-speaking people ...

\section{(e) Ambiguous definitions}

The old-fashioned term Muhammedan is defined in Webster's in a vague style in an obvious attempt to avoid the offensive meaning that relates the adjective to the followers of Muhammed or Islam in older titles by Merriam-Webster's publishers, e.g. Webster's II New Riverside University Dictionary. But the present definition can still be interpreted as referring to the people, not just to the prophet or the religion. In the other two dictionaries, the compilers have been careful to indicate explicitly that this term is not favoured by Muslims who do not refer to Muhammed as a founder of their religion but rather as God's messenger.

LDCE Mohammedan ... a word meaning Muslim, now considered offensive by most Muslims

NODE Muhammadan ... archaic term for Muslim (not favored by Muslims)

Webster's Mohammadan ... of or relating to Muhammad or Islam 


\section{(f) Incomplete information}

Some definitions of Islamic terms in English dictionaries reflect their compilers' inadequate knowledge of foreign cultures and the little effort they make to find the correct information in the proper sources. A good example is the entry for haj in an earlier edition of Webster's where the term was defined as 'pilgrimage to Mecca during Ramadan'. It is known that haj takes place during another Islamic month, Dhu'l-Hijja. But it seems that the publishers have become aware of this error and the correction has been made in later editions. A clearer definition of the same term is needed in NODE where haj is defined as 'the pilgrimage to Mecca which takes place in the last month of the year'. The dictionary does not specify which year it is, the Gregorian or the Islamic year.

LDCE haj ... a journey to Mecca for religious reasons, that all Muslims try to make at least once in their life

NODE hajj ... the Muslim pilgrimage to Mecca which takes place in the last month of the year, and which all Muslims are expected to make at least once during their lifetime

Webster's haj ...the pilgrimage to Mecca prescribed as a religious duty for Muslims

\section{(g) Narrow definitions}

The Arabic meaning of mosque is not restricted to a building for worship but it can refer to any place where a Muslim can perform the daily prayers. Only NODE's definition is consistent with this meaning while the other two dictionaries define this common word using the words 'house' and 'building' in their definitions.

LDCE mosque ... a building in which Muslims worship

NODE mosque ... a Muslim place of worship

Webster's mosque ... a Muslim house of worship

\section{(h) Encyclopedic redundancy}

There does not seem to be any specific degree of encyclopedity in the definitions of Islamic terms in English dictionaries. In some entries, a dearth of essential encyclopedic details is found, while in other entries there is an abundance of encyclopedic information. For example, in the entry for Shia in Webster's, this smaller branch of Islam has been defined in an entry the size of 
which is almost twice the size of the entry for Sunni, the mainstream Islam. This definition contains other Islamic terms that require further searching on the part of the user, e.g. Ali, Imams, Muhammad and the last recognized Imam.

LDCE Shia ... the Siite branch of the Muslim religion ...

NODE Shia ... one of the two main branches of Islam, followed especially in Iran, that rejects the first three caliphs and regards Ali, the fourth caliph, as Muhammad's first true successor ...

Webster's Shia ... the Muslims of the branch of Islam comprising sects believing in Ali and the Imams as the only rightful successors of Muhammad and in the concealment and messianic return of the last recognized Imam

\section{Conclusion}

Dictionaries can play a vital role in promoting cultural understanding and dispelling preconceived notions and stereotypes about other ethnicities and religions. We have found that, despite the critical remarks raised above regarding dictionary definitional inconsistencies, the three major English dictionaries examined in this study provide a comparatively more objective image of Islam and the Arab world than what people usually see and read in the mass media and many works of literature, despite the fact that the compilers of these dictionaries are influenced by their social environments and views of other cultures with obviously inadequate access to the original Islamic sources. It is not suggested in this paper that English dictionaries of different sizes should reflect Arabic native speakers' knowledge of Islamic terms. Rather, we have tried to show that there remains some room for better treatment of terms relating to Islam in English lexicography. With the help of corpus evidence which will probably include material produced by English-speaking Muslims, the list of Islamic terms can be revised in order to accommodate common Islamic terms that have recently become of wide currency in different types of printed materials. In addition, definitions of these terms can be reconsidered to provide native speakers and learners of English worldwide with clearer, more accurate, objective and sufficient information that is essential for them to understand Islam and the Arab world.

\section{References}

\section{Dictionaries}

Kipfer, B. (Ed.). Roget's Thesaurus [online]. Available at $<\mathrm{http}$ ://www.thesaurus.com>.

Mish, F.C. (Ed.). 2003"11. Merriam-Webster's Collegiate Dictionary. Springfield, MA: Merriam-Webster. 
Pearsall, J. and P. Hanks (Eds.). 1998. New Oxford Dictionary of English. Oxford: Oxford University Press.

Soanes, C. and A. Stevenson (Eds.). 2003. Oxford Dictionary of English. Oxford: Oxford University Press.

Soukhanov, A.H. and K. Ellis (Eds.). 1984. Webster's II New Riverside University Dictionary. Boston, MA: Houghton Mifflin Company.

Summers, D. et al. (Eds.). 2001³. Longman Dictionary of Contemporary English. Harlow: Longman.

\section{Other sources}

Benson, Philip. 1997. The Lexicography of English in the World: The Treatment of China in Four British Dictionaries. Ph.D. Thesis. Exeter: University of Exeter.

Brown, A. 1996. The Treatment of Religious Terminology in English Dictionaries. Khan, J.U. and A.E. Hare (Eds.). English and Islam, Creative Encounters 96: Proceedings of the International Conference Organized by the Department of English Language and Literature, International Islamic University Malaysia, Kuala Lumpur, 20-22 December 1996: 307-314. Kuala Lumpur: Research Centre, International Islamic University Malaysia.

Burchfield, R.W. 1989. Unlocking the English Language. London: Faber and Faber.

Cowie, A.P. 1995. The Learner's Dictionary in a Changing Cultural Perspective. Kachru, B.B. and H. Kahane (Eds.). Cultures, Ideologies and the Dictionary: 283-295. Lexicographica. Series Maior 64. Tubingen: Max Niemeyer.

Landau, S.I. 1989. Dictionaries: The Art and Craft of Lexicography. Cambridge: Cambridge University Press.

Moon, R. 1989. Objective or Objectionable? Ideological Aspects of Dictionaries. English Language Research 3: 59-94.

Poole, Elizabeth. 2002. Reporting Islam: Media Representations of British Muslims. London: I.B. Tauris Publishers.

Rosen, Lawrance. 2002. The Culture of Islam: Changing Aspects of Contemporary Muslim Life. Chicago: Chicago University Press.

UNESCO. 2001. Universal Declaration on Cultural Diversity. Adopted by the 31st Session of the General Conference of UNESCO, Paris, 2 November 2001. 
Appendix: Arab-Islamic vocabulary in the wordlist

\begin{tabular}{|c|c|c|c|}
\hline Term & $L D C E$ & NODE & Webster's \\
\hline Ashura & - & - & - \\
\hline Abbasid & - & $\checkmark$ & - \\
\hline adhan & - & - & - \\
\hline Ahlul Bayt & - & $\checkmark$ & - \\
\hline Allah & $\checkmark$ & $\checkmark$ & $\checkmark$ \\
\hline ayah & - & - & - \\
\hline Ayatollah & $\checkmark$ & $\checkmark$ & $\checkmark$ \\
\hline caliph & $\checkmark$ & $\checkmark$ & $\checkmark$ \\
\hline da'wah & - & - & - \\
\hline dervish & $\checkmark$ & $\checkmark$ & $\checkmark$ \\
\hline Druze & - & $\checkmark$ & $\checkmark$ \\
\hline Eid & - & $\checkmark$ & - \\
\hline fard & - & - & - \\
\hline fatwa & $\checkmark$ & $\checkmark$ & $\checkmark$ \\
\hline fiqh & - & - & - \\
\hline fitnah & - & - & - \\
\hline Hadith & - & $\checkmark$ & $\checkmark$ \\
\hline halal & $\checkmark$ & $\checkmark$ & $\checkmark$ \\
\hline haj & $\checkmark$ & $\checkmark$ & $\checkmark$ \\
\hline Hamas & - & $\checkmark$ & - \\
\hline haram & - & $\checkmark$ & - \\
\hline hijab & - & - & - \\
\hline Hijrah & - & $\checkmark$ & $\checkmark$ \\
\hline Hizb Allah & - & $\checkmark$ & - \\
\hline Iblis & - & - & - \\
\hline iftar & - & $\checkmark$ & - \\
\hline Imam & $\checkmark$ & $\checkmark$ & $\checkmark$ \\
\hline Injil & - & - & - \\
\hline Islam & $\checkmark$ & $\checkmark$ & $\checkmark$ \\
\hline Jannah & - & - & - \\
\hline jihad & $\checkmark$ & $\checkmark$ & $\checkmark$ \\
\hline jinn & $\checkmark$ & $\checkmark$ & $\checkmark$ \\
\hline Jumuah & - & - & - \\
\hline Ka'ba & - & $\checkmark$ & $\checkmark$ \\
\hline kafir & $\checkmark$ & $\checkmark$ & - \\
\hline Koran & $\checkmark$ & $\checkmark$ & $\checkmark$ \\
\hline madrasa & - & $\checkmark$ & $\checkmark$ \\
\hline Mahdi & - & $\checkmark$ & $\checkmark$ \\
\hline masjid & - & $\checkmark$ & - \\
\hline Месcа & $\checkmark$ & $\checkmark$ & $\checkmark$ \\
\hline Medina & - & $\checkmark$ & - \\
\hline
\end{tabular}




\begin{tabular}{|c|c|c|c|}
\hline Term & $L D C E$ & NODE & Webster's \\
\hline minaret & $\checkmark$ & $\checkmark$ & $\checkmark$ \\
\hline Miraj & - & - & - \\
\hline muezzin & $\checkmark$ & $\checkmark$ & $\checkmark$ \\
\hline mufti & $\checkmark$ & $\checkmark$ & $\checkmark$ \\
\hline mujahid & - & - & $\checkmark$ \\
\hline mullah & $\checkmark$ & $\checkmark$ & $\checkmark$ \\
\hline Muslim & $\checkmark$ & $\checkmark$ & $\checkmark$ \\
\hline niqab & - & - & - \\
\hline P.B.U.H. & - & - & - \\
\hline kadi & - & $\checkmark$ & - \\
\hline qibla & - & $\checkmark$ & - \\
\hline Ramadhan & $\checkmark$ & $\checkmark$ & $\checkmark$ \\
\hline salat & - & $\checkmark$ & - \\
\hline salafism & - & - & - \\
\hline salaam & - & - & - \\
\hline sawm & - & - & - \\
\hline shahadah & - & $\checkmark$ & - \\
\hline shaheed & - & $\checkmark$ & - \\
\hline sheik & $\checkmark$ & $\checkmark$ & $\checkmark$ \\
\hline Shia & $\checkmark$ & $\checkmark$ & $\checkmark$ \\
\hline Shi'ite & $\checkmark$ & $\checkmark$ & $\checkmark$ \\
\hline shirk & - & - & - \\
\hline shura & - & $\checkmark$ & - \\
\hline sufi & - & $\checkmark$ & - \\
\hline Sunnah & $\checkmark$ & $\checkmark$ & $\checkmark$ \\
\hline Sunni & $\checkmark$ & $\checkmark$ & $\checkmark$ \\
\hline surah & - & $\checkmark$ & $\checkmark$ \\
\hline ummah & - & $\checkmark$ & - \\
\hline umrah & - & - & - \\
\hline Whhabism & - & $\checkmark$ & $\checkmark$ \\
\hline zakat & - & $\checkmark$ & - \\
\hline Zaboor & - & - & \\
\hline Total $=73$ & $5(34.2 \%)$ & $51(69.9 \%)$ & $33(45.2 \%)$ \\
\hline
\end{tabular}

